\title{
Interaction of Carbon Nanohorns with Plants: Uptake and Biological Effects
}

Mohamed H. Lahiani ${ }^{1}$, Jihua Chen ${ }^{2}$, Fahmida Irin ${ }^{3}$, Alexander A. Puretzky ${ }^{2}$, Micah J. Green ${ }^{4}$ and Mariya V. Khodakovskaya ${ }^{I}$

${ }^{1}$ Department of Applied Science, University of Arkansas at Little Rock, Little Rock, AR 72204, ${ }^{2}$ Center for Nanophase Materials Sciences, Oak Ridge National Laboratory, Oak Ridge, TN 37831

${ }^{3}$ Department of Chemical Engineering, Texas Tech University, Lubbock, TX, 79409

${ }^{4}$ Artie McFerrin Department of Chemical Engineering, Texas A\&M University, College Station, TX 77843

*Author for correspondence

E-mail: mvkhodakovsk@ualr.edu

Phone: 501-683-2656

Fax: 501-569-8020 
Keywords: Carbon nanohorns, nanoparticles, germination, crops, microarray, gene expression, microwave induced heating technique.

\begin{abstract}
Single-Walled Carbon Nanohorns (SWCNHs) are a unique carbon-based nanomaterial with promising application in different fields including, medicine, genetic engineering and horticulture. Here, we investigated the biological response of six crop species (barley, corn, rice, soybean, switchgrass, tomato) and tobacco cell culture to the exposure of SWCNHs. We found that SWCNHs can activate seed germination of selected crops and enhance growth of different organs of corn, tomato, rice and soybean. At cellular level, growth of tobacco cells was increased in response to exposure of SWCNHs (78\% increase compared to control). Uptake of SWCNHs by exposed crops and tobacco cells was confirmed by transmission electron microscopy (TEM) and quantified by microwave induced heating $(\mathrm{MIH})$ technique. At genetic level, SWCNHs were able to affect expression of a number of tomato genes that are involved in stress responses, cellular responses and metabolic processes. We have concluded that SWCNHs can be used as plant growth regulators and have the potential for plant-related applications.
\end{abstract}




\section{Introduction}

Carbonaceous nanostructures are new materials that have wide range of applications including electronics [1,2], medicine [3-5], aerospace and agriculture [6]. Among carbon-based nanomaterial, single-walled carbon nanotubes (SWCNTs) and multi-walled carbon nanotubes (MWCNTs) have attracted plant biologists due to their positive effect on growth of different crops [7-9] and their potential use as smart delivery systems in plants [10-13]. Single-walled carbon nanohorns (SWCNHs) are another promising carbonaceous nanosized material with distinctive characteristics. Unlike carbon nanotubes, nanohorns are uniform in size and can be well dispersed in solvents [14-17]. Moreover, they can be synthesized in large quantities without any catalyst [17,18]. The metal contamination in different carbon-based nanomaterials including, graphene [19], carbon nanotubes [20], fullerenes [21], nanodiamonds [22], and nanofibers [23] can modify the response of plant. Therefore, the purity of the nanomaterial remains an essential factor to guarantee reproducible biological effects.

SWCNHs are single graphitic tubules with diameter of 2-5 nm and lengths of 40-50 nm [24,25]. Three different types of SWCNHs have been observed including 'dahlia-like', 'bud-like' and 'seedlike' [25]. SWCNHs exist in spherical aggregate with a diameter of 50-100 nm (Figure 1A). The cylindrical inner nanospace and interstitial channels are among the features that distinguish nanohorns from other carbonaceous nanomaterials [17] (Figure 1A). In fact, the inner nanospace is large enough to store a large amount of molecules of interest. For this reason, SWCNHs are a good candidate for gas storage [26-28], molecules adsorption [29,30] and drug delivery [31-33] However, concerns about the toxicity and other hazards caused by occupational exposure to this new material remain active $[15,34]$. 
Toxicological studies on two bacterial organisms including, S. typhimuium and E. coli strains showed that SWCNHs did not have either growth inhibitory effect or an increase in the number of revertant [15]. Moreover, in vivo toxicological studies on rabbits, guinea pigs and rats have been conducted to test skin primary irritation, eye irritation, skin sensitization, peroral administration and intratracheal instillation [15]. No abnormalities were shown in the tested animals, in either the skin or eye irritation tests. Furthermore, the oral administration of $2000 \mathrm{mg} / \mathrm{kg}$ body weight of SWCNHs was not sufficient to illustrate any sign of toxicity even after the 2-week test period [15]. Recent histological studies have shown that SWCNHs can be accumulated in liver and spleen with no symptoms of hematological or immunological toxicity [34]. All the initial reports on SWCNHs toxicity approve the safety of this nanomaterial. However, the numerous applications of SWCNHs can facilitate their release to the environment and, therefore, the impact of SWCNHs on a larger number of organisms should be evaluated.

Unique properties of SWCNHs including the presence of inner nanospace are making them attractive candidates for use as 'smart' delivery systems in a range of plant-related applications. For example, SWCNHs can be used for delivery of DNA, proteins and chemicals including herbicides. However, in order to initiate such investigations, assessment of plant response to direct exposure of SWCNHs to plants and plant cells has to be performed. Recently, we demonstrated that two types of carbon nanotubes (MWCNTs and SWCNTs) could penetrate seed coats, activate seed germination, and plant growth in low doses $[8,9,35]$. Here, we describe the consequences of exposure of SWCNHs to different plant tissues including seeds, whole plants and plant cell culture. The uptake of SWCNHs was detected using TEM and quantified using MIH technique [36]. The genes that were affected by application of SWCNHs to tomato seeds and seedlings were identified by microarray analysis (Affymetrix platform). 


\section{Experimental methods}

\subsection{Synthesis and Characterization of SWCNHs}

Single wall carbon nanohorns (SWCNHs) were synthesized using high power laser vaporization setup as described early [37,38]. Briefly, the experimental setup includes a quartz tube reactor mounted inside a tube furnace operating at $1150^{\circ} \mathrm{C}$ with flowing Argon (flow rate $4600 \mathrm{sscm}$ ) at atmospheric pressure. The Nd: YAG laser light $(\lambda=1.064 \mu \mathrm{m}, 20 \mathrm{~ms}$ pulse width, $90 \mathrm{~J} / \mathrm{pulse}, 5 \mathrm{~Hz}$ repetition rate) was used to vaporize a carbon target located in the center of the quartz tube reactor. Using this approach, we are able to produce relatively large amounts of long SWCNHs with the production rates of $10 \mathrm{~g} / \mathrm{h}$. SWCNHs were characterized using scanning and transmission electron microscopy (SEM and TEM), thermogravimetric analysis (TGA), and Raman scattering [37,38]..

\subsection{Plant Growth and Seed Germination}

Seeds, including soybean hybrid S42-T4, barley hybrid Robust and corn hybrid N79Z 300GT, were obtained from Syngenta, Inc (Greensboro, NC), Micro-Tom tomato seeds were obtained from Reimer seeds (Saint Leonard, MD). Switch grass seeds were purchased from Sheffield's Seed Company and rice seeds (cv. Cypress) were obtained from USDA (Reg. no. CV-91, PI 561734). SWCNHs were dispersed in water solution using a QSonica, LLC (Newtown, CT). Standard Murashige and Skoog medium (MS medium) was supplemented with different concentrations of SWCNHs $(25,50$ and $100 \mu \mathrm{g} / \mathrm{ml})$. The MS medium without SWCNHs was used as a control medium. All seeds were sterilized as following: soybean seeds were sterilized with chlorine gas overnight as previously shown by Paz et al.[39]. Barley seeds were treated with a solution of 50\% $\mathrm{H}_{2} \mathrm{SO}_{4}$ for 15 minutes. Corn seeds were pre-treated with soapy water and $80 \%$ ethanol and kept in $50 \%$ bleach for 15 minutes. Switch grass seeds were pre-treated with a solution of $60 \% \mathrm{H}_{2} \mathrm{SO}_{4}$ for 30 min and kept in $100 \%$ bleach with $0.05 \%$ tween for 30 minutes [40]. Tomato seeds were pre- 
treated with $80 \%$ ethanol and then soaked in $30 \%$ bleach. Rice seeds were milled and sterilized as described by Oyebanji et al.[41]. All seeds were washed thoroughly using deionized autoclaved water and placed on a medium in Magenta boxes and incubated at $25^{\circ} \mathrm{C}$. Phenotypic measurement of barley (11 day-old), corn (10 day-old), rice (12 day-old), soybean (11 day-old), switch-grass and tomato (20 day-old) seedlings were assessed. Root, shoot, and leaf lengths were evaluated. The fresh weight of roots and shoots was measured. Seedlings were dried in a hot oven at $75^{\circ} \mathrm{C}$ overnight, and the dry weight was measured. All data were analyzed using ANOVA and post-hoc analysis using the Tukey test for treatment differences.

\subsection{Statistics for Tests of Germination and Plant Growth}

All assays were performed in triplicate. All figures are represented as mean values \pm SE (standard errors). All data were analyzed using SPSS ${ }^{\circ}$ software by performing ANOVA and posthoc analysis using the Tukey test for treatment differences. $\mathrm{P}<0.05$ determined statistical significance.

\subsection{Callus Growth and Treatment}

Callus tobacco culture was established as described previously by Khodakovskaya et al. [8]. Briefly, tobacco leaf explants were used to induce callus production in dark condition for one month. The calli were excised from the leaves, transferred to a fresh medium and kept in a tissue culture growth chamber at $22-24{ }^{\circ} \mathrm{C}$. Callus growth was tested using special tubes for plant cell culture (Phytotechnology Laboratories, Inc.). An equal amount of initial callus (inoculum), 300 mg, was placed in each experimental tube containing agar medium with or without SWCNHs. The control medium was MS medium supplemented with $1 \mathrm{mg} / \mathrm{L}$ 2,4-Dichlorophenoxyacetic acid and the SWCNHs medium was composed of the control medium mixed with SWCNHs at 
concentrations of 25, 50 and $100 \mu \mathrm{g} / \mathrm{ml}$. Experimental tubes were kept in dark conditions at 22-24 ${ }^{\circ} \mathrm{C}$ in a growth chamber for 1 month. Each experimental condition was replicated 10 times (10 tubes were used for each concentration of carbon nanohorns or control medium). After measurement of fresh weight of callus produced in each tube, samples were dried in a hot oven at $75^{\circ} \mathrm{C}$ overnight. Subsequently, dry weight was measured for all samples.

\subsection{TEM Analysis of Seeds, Roots and Callus Culture Exposed to SWCNHs}

Samples of tomato seeds and roots, as well as callus culture exposed to MS medium supplemented with SWCNHs and control seeds exposed to regular MS medium, were fixed in 3\% GTA in 0.075M Sörensen's buffer [42] , pH 7.2 at $4^{\circ} \mathrm{C}$, for at least 48 hours. Samples were washed for three times for 30 minutes in cold $0.075 \mathrm{M}$ Sörensen's buffer, $\mathrm{pH} 7.2$; and then post-fixed in $1 \% \mathrm{OsO} 4$ in the same buffer for 2 hours, on ice and in the dark, and finally washed three times 30 minutes in the same buffer. Samples were dehydrated with a graded ethanol series $(30,50,70,95$, and three times with $100 \%$ ) and then infiltrated with Spurr's resin. Blocks were sectioned using an LKB NOVA Ultramicrotome at 75-90 nm; sections were collected on 150-mesh formvar/carbon grids (Ladd Research). Grids were stained with $4 \%$ uranyl acetate for one hour at room temperature and four minutes in Reynolds' lead citrate. TEM samples were examined with an inline energy filtered Zeiss Libra 120 at $120 \mathrm{kV}$ along with an emission current of about $5 \mu \mathrm{A}$. Samples are monitored carefully before and after imaging, and a minimum beam condition is used efficiently to mitigate the impact of electron beam damage.

\subsection{Detection and Quantification of SWCNH Using Microwave Induced Heating Technique}


The amount of SWCNHs uptake by the corn root and shoot samples were tested by microwave induced heating (MIH) technique. The method was described by Irin et al. [36]. This method quantitatively detects SWCNH by the temperature rise due to the absorption of microwave power. Both MWCNTs and SWCNHs have high microwave absorption capacity, which results in a rapid rise in temperature within a very short microwave exposure time. SWCNHs have a lower microwave response compared to MWCNTs. To check the sensitivity, $\sim 1 \mathrm{mg}$ SWCNH powder sample was (not in plant biomass) exposed to $30 \mathrm{~W}$ microwave power (2.45 $\mathrm{GHz}$ frequency), and the final temperature rise was recorded immediately (within one second). The temperature rise $(\Delta \mathrm{T})$ of SWCNH samples were measured as $265{ }^{\circ} \mathrm{C}$. This $\Delta \mathrm{T}$ measurement was repeatable over many trials with a variation under $20{ }^{\circ} \mathrm{C}$. This confirms that SWCNH displayed less microwave heating compared to SWCNT and MWCNT for a given microwave power and time. This value was used to determine the slope of the calibration curve (renormalized from Irin et al. [36]) which varies with the type of nanomaterial. The detailed procedure is described in the result and discussion section. To estimate the average amount of SWCNHs absorbed by different plant roots ( $\mu \mathrm{g} \mathrm{SWCNH} /$ plant root), we multiplied the average amount measured $(\mu \mathrm{g} \mathrm{SWCNH} / \mathrm{mg}$ ) by the average dry weight of the root (mg dry weight of root). Knowing that each cultivation vessel contained a total amount of $6000 \mu \mathrm{g}$ SWCNHs (100\%), we calculated the average percentage of uptake of the nanoparticle per root system of each plant (\% SWCNH plant uptake/ box). In the case of callus culture, the cultivation vessel contained $2000 \mu \mathrm{g}$ SWCNHs (100\%).

\subsection{Microarray of Seeds and Seedlings Exposed to SWCNHs}

Tomato seeds (exposed for 1 day) and seedling (11 days-old) exposed to SWCNHs ( $25 \mu \mathrm{g} / \mathrm{mL})$ and not exposed were harvested and snap-frozen in liquid nitrogen. Total RNA from control and exposed seeds and seedlings were isolated using RNeasy Plant Mini Kit (Qiagen Inc. Valencia, 
CA). RNA from exposed and unexposed plant tissues was extracted using the PureLink® Plant RNA reagent protocol (Life Technologies, Grand Island, NY). Residual DNA was removed by oncolumn DNA digestion using the RNase-free DNase Kit (Qiagen Inc. Valencia, CA). Residual DNA from all RNA samples was removed by on-column DNA digestion using the RNase-free DNase Kit (Qiagen Inc. Valencia, CA). Microarray analysis was performed using mRNA of the tomato tissues, in three independent biological replicates. Tomato seed samples contained 30 seeds each and tomato seedlings replicates contained three individual plants. Affymetrix Tomato Genome Arrays methodology was used for our experiment. Biotinylated cRNA targets were synthesized according to Affymetrix IVT Express target labeling assay as specified in the Affymetrix GeneChip Expression Analysis Technical Manual. Hybridization reactions to the Affymetrix Tomato GeneChips were carried out by Expression Analysis, Inc. The differences in transcript abundance of several genes identified by microarray analysis were validated by using real-time RT-qPCR (SYBR Green detection) for three different genes (Les.50.1.S1_at Ribonuclease, Les.3635.1S1_at Subtiliselike protease and Les.1841.1.S1_at 1-aminocyclopropane-1-carboxylate synthase). Complementary DNA (cDNA) was synthesized for each sample using the SuperScript ${ }^{\mathrm{TM}}$ III First-Strand Synthesis System (Invitrogen). RT-qPCR assay was performed and analyzed as described earlier [8]. The corresponding primers used for amplification of genes in real time PCR were: Les.50.1.S1_at Ribonuclease 5'CTTGCCCTAGTAGTGATGGTTT-3' (forward primer) and 5'GTCAAGTGCAGTTTGGAAATAGG-3' (reverse primer), Les.3635.1S1_at Subtilise-like protease 5'-CTGATACAACGCAGGGTGAA-3' (forward primer) and 5'GAGGAGTTGATCCAAGTCCAAATA-3' (reverse primer), Les.1841.1.S1_at 1aminocyclopropane-1-carboxylate synthase 5'-GAGGCAGAGGAAAGTACACAAG-3' (forward primer) 5'-GCTTCAAATCTTGGCTCTTTGG-3' (reverse primer). 18S was used as an internal standard and was amplified using these primers: 5'-AGGCCGCGGAAGTTTGAGGC-3' (forward 
primer) and 5'-ATCAGTGTAGCGCGCGTGGG-3' (reverse primer). Relative expression levels were normalized to the internal standard (18S transcript) for each treatment. For each relative quantity determination, three independent replicates were used.

\subsection{Statistical Analysis of Microarray Data and Biological Processes Analysis}

Microarray data was normalized using generalized logarithm transformation and using the control group as a reference. Data was visualized using TM4® Software, Multi Experiment viewer (Mev). The significantly SWCNHs-affected genes were detected by running an unpaired t-test analysis with a $p$-value of 0.01 . All genes were clustered by hierarchical clustering (Euclidean distance). Known and unknown significant genes were calculated and graphed. The total transcript profile of significant genes of tomato seeds and seedlings are presented in supplemental figures S3 and S4. Only significant known genes are presented in figures 5 and 6 . Using the Tomato Functional Genomic Database, significantly SWCNHs-altered genes were categorized by biological cellular processes (http://ted.bti.cornell.edu/cgiin/TFGD/array/funcat.cgi). All generated microarray data is deposited in public database GEO under accession number GSE57541.

\section{Results and Discussion}

\subsection{Synthesis and Characterization of Single-walled Carbon Nanohorns (SWCNHs)}

The SWCNHs were synthesized using high power laser vaporization of pure carbon targets into a background gas (Ar) at atmospheric pressure and elevated temperatures $\left(1100^{\circ} \mathrm{C}\right)$. The synthesis and characterization processes have been described early. [37,38] SEM images (Figure 1B) show $\sim 50-100 \mathrm{~nm}$ SWNH aggregate balls that form a mesoporous agglomerate structure. Each of these balls, which are represented schematically in Figure 1A, contains hundreds of individual nanohorns units. Each aggregate ball contains the internal pores (open nanospace inside each nanohorns unit) 
plus interstitial pores determined by close packing of these individual units - as shown in Figure $1 \mathrm{~A}$.
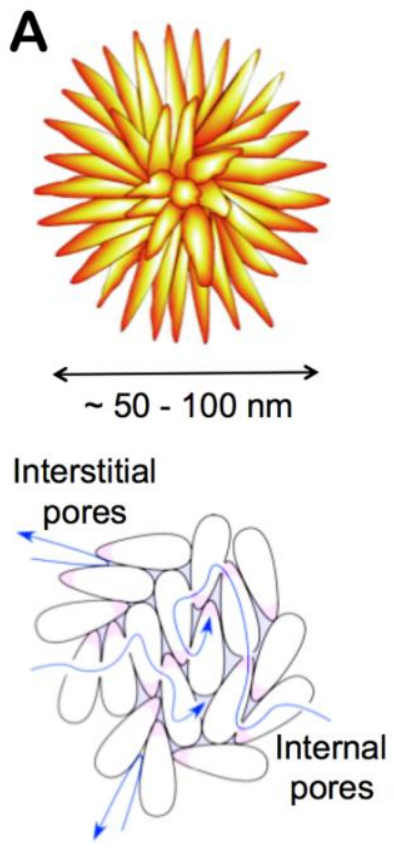
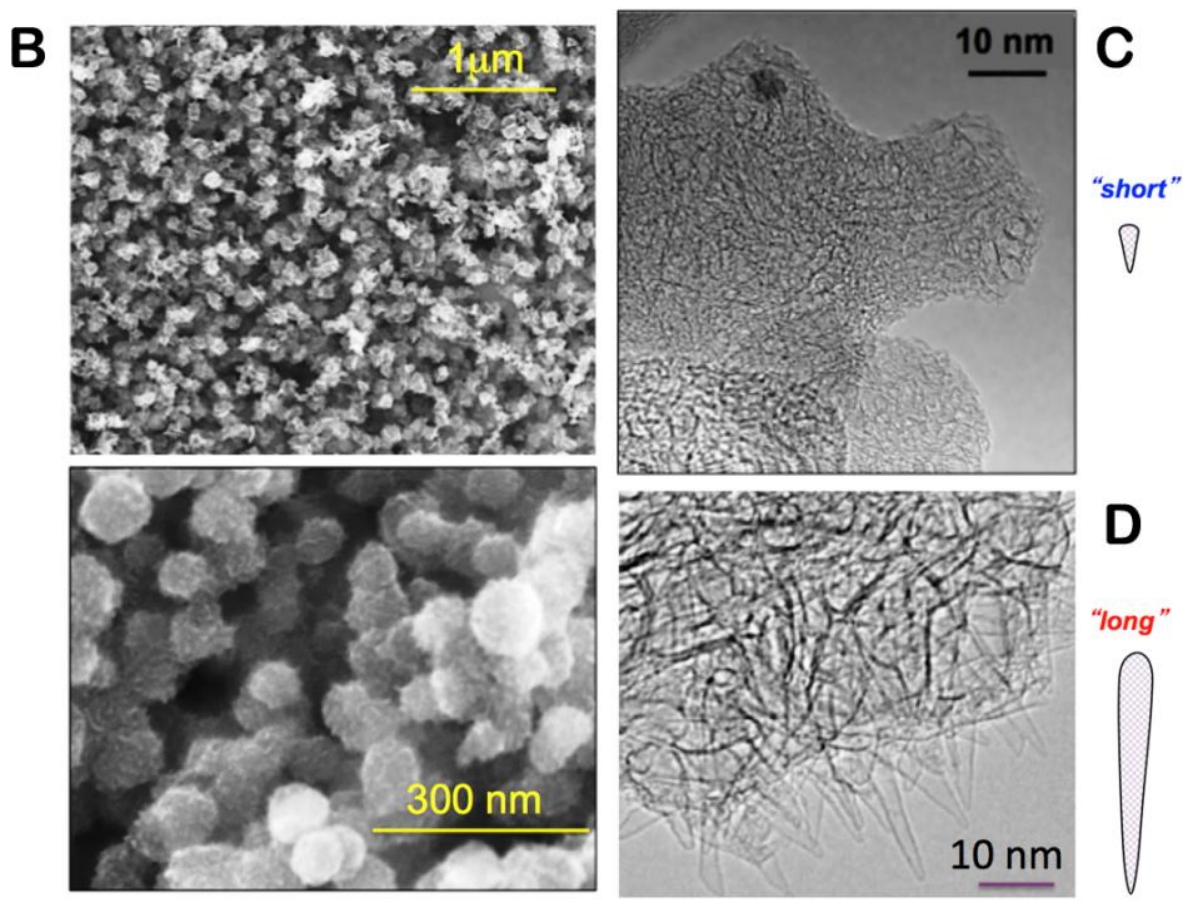

Figure 1. (A) Schematic of general morphology of a SWCNH aggregate showing internal and interstitial pores (bottom). (B) SEM images of SWCNH aggregates both in close-view (bottom) and in far-view (top) showing the mesoporous agglomerate of SWCNH aggregates. High-resolution TEM images of SWCNH aggregates, and schematic of individual (C) "short" and (D) "long" SWCNH units, some of which protrude from the aggregate.

Through adjusting the parameters of the synthesis process, we can control the length of the individual nanohorn units, and, therefore, their internal pore diameters. [37,38] These parameters simultaneously determine their packing, the interstitial pore size of the aggregates, and the macroporosity of the nanohorns agglomerates. For example, TEM images in Figure 1C show nanohorns morphologies in two limiting cases, i.e., "long" and "short" SWCNHs. SWCNHs are very much like carbon nanotubes, but are much more amenable to processing techniques. SWCNTs, for 
example, can be synthesized by the same laser ablation approach, but the process requires metal catalysts such as $\mathrm{Ni}, \mathrm{Co}$, or $\mathrm{Fe}$ that are relatively difficult to remove [43,44]. As-synthesized SWCNHs do not require purification; they are nonreactive and nontoxic, and are extremely robust to withstand very high temperatures and pressures. They can be activated with gas-phase $\mathrm{CO}_{2}$ thermal treatments to open their internal pores. For example, using this treatment, the as synthesized BET surface area of the SWCNHs can be increased from 450 to $2100 \mathrm{~m}^{2} / \mathrm{g}$, and the pore sizes of the nanohorns can be increased, e.g., for hydrogen storage [45]. Activated SWCNHs are easily dispersed into water, which is ideal for bio-applications [4,5]. Moreover, we have demonstrated that activated SWCNHs can be decorated [45], filled [34], functionalized, and deposited easily by electrophoresis onto arbitrary substrates for use as electrode materials [46]. It will be promising to test nanohorns as carriers for delivery of biological molecules and chemicals to plant organs/plant cells. However, firstly we need to prove that SWCNHs are not toxic for plant/plant cells and investigate the biological response of plants on exposure to SWCNHs. We have designed experiments focused on evaluation of germination, development, cell growth and gene expression in different plant species exposed to nanohorns through growth medium. We have used "long" carbon nanohorns (Figure 1D) for all designed experiments.

\subsection{Effect of SWCNHs on Seed Germination and Growth of Different Crop Species:}

In order to assess the response of different plant species to exposure of SWCNHs, we monitored seed germination and plant growth of six commercially important species: barley, corn, soybean, rice, switchgrass and tomato. Delivery of SWCNHs was performed by the introduction of nanomaterial to the Murashige and Skoog growth medium (MS medium). We found that the exposure to SWCNHs affected the germination time and rate of valuable crops (Figure 2). 

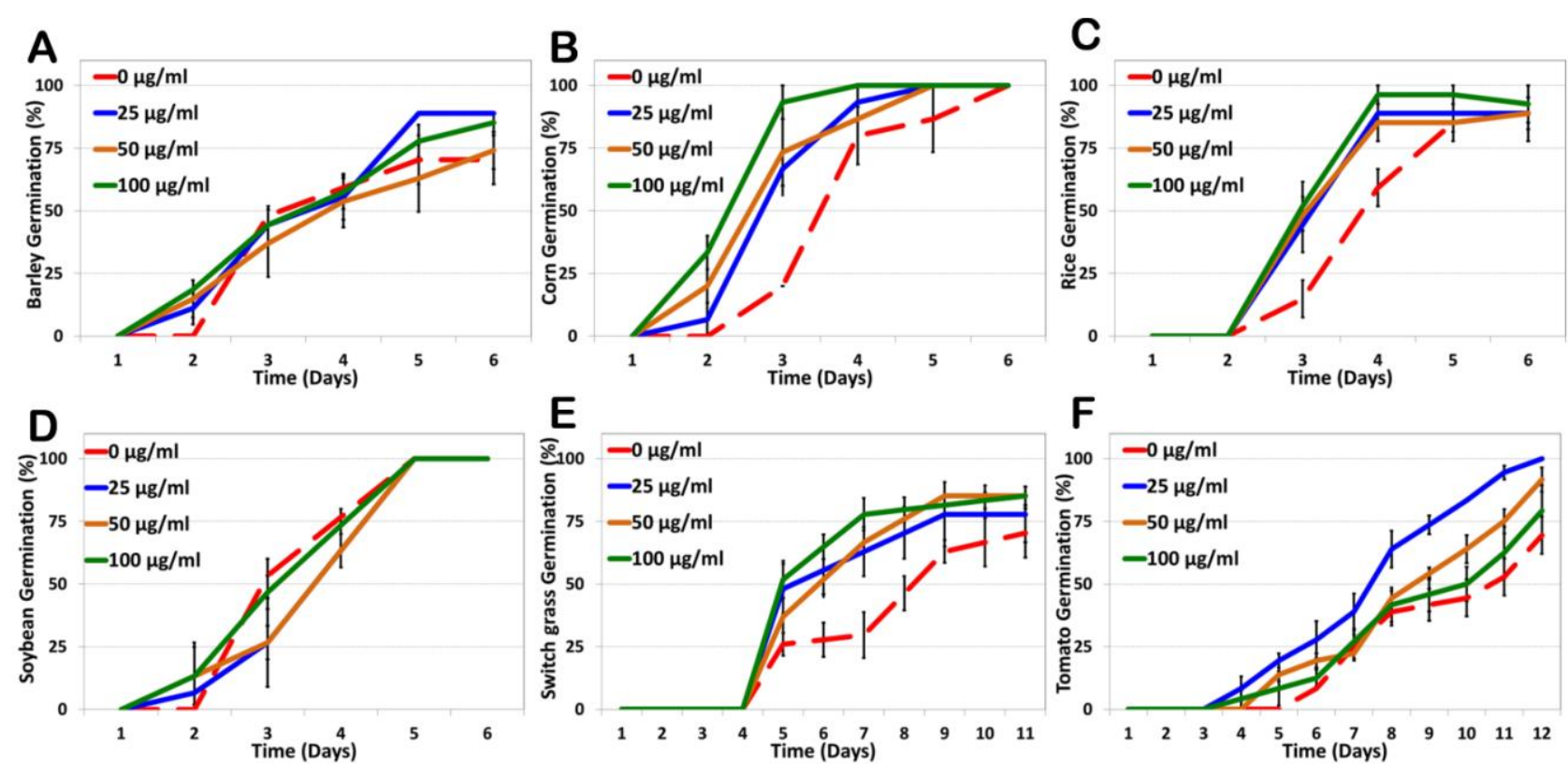

Figure 2. Effect of SWCNHs on the germination of seeds from different crop species. Seeds germination is presented as a percentage. (A) barley, (B) corn, (C) rice, (D) soybean, (E) switchgrass and (F) tomato seeds were incubated on MS medium supplemented with SWCNHs at $25 \mu \mathrm{g} / \mathrm{ml}, 50 \mu \mathrm{g} / \mathrm{ml}$ and $100 \mu \mathrm{g} / \mathrm{ml}$. Controls included seeds grown on regular MS medium(0 $\mu \mathrm{g} / \mathrm{ml}) .{ }^{*}, p<0.05$ compared to control. Vertical bars indicate $\pm \mathrm{SE}$.

Thus, the early germination was observed for SWCNHs-exposed barley $(100 \mu \mathrm{g} / \mathrm{ml})$, corn ( all concentrations)-, rice (all concentrations), switchgrass (all concentrations) and tomato seeds (25 and $50 \mu \mathrm{g} / \mathrm{ml})(p<0.05)$ (Figure 2A, 2B, 2C, 2E and 2F). For example, while the percentage of control corn seed germination averaged $20 \%$ at day 3 post-exposure, seeds placed on SWCNHs medium $(100 \mu \mathrm{g} / \mathrm{ml})$ have reached an average of $93 \%$ of germination. The highest values of germination percentage were recorded for barley, corn, rice and switchgrass seeds exposed to $100 \mu \mathrm{g} / \mathrm{ml}$ SWCNHs. Tomato seeds, on the other hand, showed the highest value of germination when exposed to $25 \mu \mathrm{g} / \mathrm{ml}$ SWCNHs medium. SWCNHs did not result in early germination of soybean seeds (Figure 2D). The rate of seed germination was also dramatically affected in tomato seeds by 
exposure to SWCNHs. For example, by day 12 post-exposure, only $69 \%$ of unexposed tomato seeds have germinated; however, tomato seeds placed on SWCNHs medium $(25 \mu \mathrm{g} / \mathrm{ml})$ have reached $100 \%$ of germination (Figure $2 \mathrm{~F}$ ). Thus, the most effective concentrations of SWCNHs were different for different plant species (Figure 2). But it is important to mention that SWCNHs at highest used concentration $(100 \mu \mathrm{g} / \mathrm{ml})$ did not cause any negative effects on the germination of tested seeds. On the contrary, SWCNHs at this concentration stimulated process of seed germination.

As the next step, we evaluated the phenotypic characteristics of crop seedlings growing on medium supplemented with SWCNHs (Table 1, Figure S1). We documented that SWCNHs increased the length of shoot of corn, rice, soybean and tomato seedlings $(p<0.05)$. 


\begin{tabular}{|c|c|c|c|c|c|c|c|c|}
\hline & & \multicolumn{2}{|c|}{ Length (cm) } & \multirow{2}{*}{$\begin{array}{c}\text { Number } \\
\text { Leaf } \\
\end{array}$} & \multicolumn{2}{|c|}{ Fresh weight (g) } & \multicolumn{2}{|c|}{ Dry weight (g) } \\
\hline & & Shoot & Root & & Shoot & Root & Shoot & Root \\
\hline \multirow{4}{*}{ 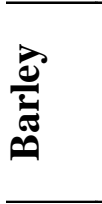 } & $0 \mu \mathrm{g} / \mathrm{ml}$ & $11.2 \pm 0.47$ & $3.8 \pm 0.35$ & $2.6 \pm 0.22$ & $0.13 \pm 0.01$ & $0.15 \pm 0.01$ & $0.014 \pm 0.01$ & $0.020 \pm 0.01$ \\
\hline & $25 \mu \mathrm{g} / \mathrm{ml}$ & $10.3 \pm 0.80$ & $3.3 \pm 0.23$ & $2.5 \pm 0.14$ & $0.11 \pm 0.01$ & $0.13 \pm 0.01$ & $0.016 \pm 0.01$ & $0.025 \pm 0.01$ \\
\hline & $50 \mu \mathrm{g} / \mathrm{ml}$ & $8.5 \pm 1.55$ & $2.7 \pm 0.41$ & $2.3 \pm 0.14$ & $0.10 \pm 0.02$ & $0.10 \pm 0.02$ & $0.016 \pm 0.02$ & $0.028 \pm 0.02$ \\
\hline & $100 \mu \mathrm{g} / \mathrm{ml}$ & $8.7 \pm 0.86$ & $2.8 \pm 0.20$ & $2.5 \pm 0.13$ & $0.10 \pm 0.01$ & $0.14 \pm 0.01$ & $0.014 \pm 0.01$ & $0.025 \pm 0.01$ \\
\hline \multirow{4}{*}{ อี } & $0 \mu \mathrm{g} / \mathrm{ml}$ & $7.2 \pm 0.43$ & $12.5 \pm 0.36$ & $1.67 \pm 0.12$ & $0.35 \pm 0.03$ & $1.80 \pm 0.14$ & $0.04 \pm 0.003$ & $0.25 \pm 0.014$ \\
\hline & $25 \mu \mathrm{g} / \mathrm{ml}$ & $7.5 \pm 0.35$ & $13.9 \pm 0.38$ & $2.1 \pm 0.17$ & $0.33 \pm 0.02$ & $1.54 \pm 0.07$ & $0.04 \pm 0.002$ & $0.23 \pm 0.007$ \\
\hline & $50 \mu \mathrm{g} / \mathrm{ml}$ & $8.9 \pm 0.44$ & $13.9 \pm 0.58$ & $2.5 \pm 0.21 b$ & $0.56 \pm 0.04 b$ & $2.02 \pm 0.06$ & $0.05 \pm 0.004$ & $0.25 \pm 0.006$ \\
\hline & $100 \mu \mathrm{g} / \mathrm{ml}$ & $9.6 \pm 0.48 b$ & $14.7 \pm 0.50 \mathrm{~b}$ & $2.4 \pm 0.14 b$ & $0.60 \pm 0.04 b$ & $1.92 \pm 0.09$ & $0.06 \pm 0.004$ & $0.23 \pm 0.009$ \\
\hline \multirow{4}{*}{ 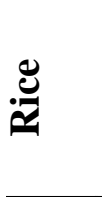 } & $0 \mu \mathrm{g} / \mathrm{ml}$ & $7.5 \pm 0.89$ & $3.0 \pm 0.26$ & $3.2 \pm 0.1$ & $0.021 \pm 0.003$ & $0.05 \pm 0.005$ & $0.005 \pm 0.0003$ & $0.021 \pm 0.0005$ \\
\hline & $25 \mu \mathrm{g} / \mathrm{ml}$ & $11.3 \pm 0.78 b$ & $2.8 \pm 0.26$ & $3.3 \pm 0.12$ & $0.036 \pm 0.003 b$ & $0.11 \pm 0.012 b$ & $0.007 \pm 0.0003 b$ & $0.021 \pm 0.0012$ \\
\hline & $50 \mu \mathrm{g} / \mathrm{ml}$ & $11.4 \pm 0.77 b$ & $3.1 \pm 0.22$ & $3.2 \pm 0.09$ & $0.031 \pm 0.003 b$ & $0.135 \pm 0.029 b$ & $0.006 \pm 0.0003 b$ & $0.022 \pm 0.0029$ \\
\hline & $100 \mu \mathrm{g} / \mathrm{ml}$ & $10.1 \pm 0.69$ & $3.0 \pm 0.25$ & $3.3 \pm 0.11$ & $0.034 \pm 0.003 b$ & $0.15 \pm 0.037 b$ & $0.007 \pm 0.0003 b$ & $0.020 \pm 0.0037$ \\
\hline \multirow{4}{*}{ 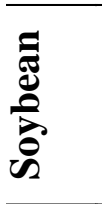 } & $0 \mu \mathrm{g} / \mathrm{ml}$ & $9.5 \pm 0.56$ & $6.5 \pm 0.42$ & $2.2 \pm 0.15$ & $0.83 \pm 0.036$ & $0.38 \pm 0.029$ & $0.15 \pm 0.0036$ & $0.035 \pm 0.0029$ \\
\hline & $25 \mu \mathrm{g} / \mathrm{ml}$ & $10.2 \pm 0.48$ & $6.5 \pm 0.32$ & $1.4 \pm 0.25$ & $0.85 \pm 0.029$ & $0.40 \pm 0.020$ & $0.15 \pm 0.0029$ & $0.037 \pm 0.0020$ \\
\hline & $50 \mu \mathrm{g} / \mathrm{ml}$ & $10.5 \pm 0.36$ & $7.2 \pm 0.25$ & $1.5 \pm 0.24$ & $0.93 \pm 0.027 b$ & $0.46 \pm 0.020$ & $0.16 \pm 0.0026$ & $0.040 \pm 0.0020$ \\
\hline & $100 \mu \mathrm{g} / \mathrm{ml}$ & $11.9 \pm 0.36 b$ & $7.1 \pm 0.32$ & $2 \pm 0.21$ & $0.93 \pm 0.013 b$ & $0.46 \pm 0.018$ & $0.15 \pm 0.0012$ & $0.040 \pm 0.0019$ \\
\hline \multirow{4}{*}{ 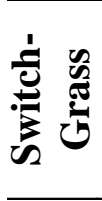 } & $0 \mu \mathrm{g} / \mathrm{ml}$ & $6.3 \pm 0.55$ & $1.9 \pm 0.19$ & $2.2 \pm 0.09$ & $0.014 \pm 0.0031$ & $0.012 \pm 0.0017$ & $0.0020 \pm 3.1 \mathrm{E}-04$ & $0.0018 \pm 0.00017$ \\
\hline & $25 \mu \mathrm{g} / \mathrm{ml}$ & $6.9 \pm 0.40$ & $1.8 \pm 0.14$ & $2.2 \pm 0.08$ & $0.012 \pm 0.0009$ & $0.012 \pm 0.0013$ & $0.0019 \pm 9.2 \mathrm{E}-05$ & $0.0017 \pm 0.00013$ \\
\hline & $50 \mu \mathrm{g} / \mathrm{ml}$ & $7.3 \pm 0.57$ & $1.4 \pm 0.20$ & $2 \pm 0.01$ & $0.0099 \pm 0.00086$ & $0.0096 \pm 0.0011$ & $0.0015 \pm 8.6 \mathrm{E}-05$ & $0.0013 \pm 0.00011$ \\
\hline & $100 \mu \mathrm{g} / \mathrm{ml}$ & $7.6 \pm 0.52$ & $1.8 \pm 0.20$ & $2.4 \pm 0.11$ & $0.014 \pm 0.0017$ & $0.011 \pm 0.0010$ & $0.0022 \pm 1.7 \mathrm{E}-04$ & $0.0016 \pm 0.0001$ \\
\hline \multirow{4}{*}{ 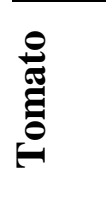 } & $0 \mu \mathrm{g} / \mathrm{ml}$ & $2.2 \pm 0.14$ & $4.5 \pm 0.20$ & $5.9 \pm 0.66$ & $0.068 \pm 0.011$ & $0.018 \pm 0.0028$ & $0.0064 \pm 0.0010$ & $0.0018 \pm 0.0010$ \\
\hline & $25 \mu \mathrm{g} / \mathrm{ml}$ & $2.5 \pm 0.15$ & $4.6 \pm 0.25$ & $7.1 \pm 0.85$ & $0.068 \pm 0.0098$ & $0.015 \pm 0.0019$ & $0.0060 \pm 0.0009$ & $0.0017 \pm 0.0010$ \\
\hline & $50 \mu \mathrm{g} / \mathrm{ml}$ & $2.8 \pm 0.14 b$ & $4.9 \pm 0.25$ & $8.1 \pm 0.70 b$ & $0.073 \pm 0.0104$ & $0.018 \pm 0.0025$ & $0.0063 \pm 0.0010$ & $0.0019 \pm 0.0002$ \\
\hline & $100 \mu \mathrm{g} / \mathrm{ml}$ & $2.5 \pm 0.10$ & $4.9 \pm 0.23$ & $8.3 \pm 0.74 b$ & $0.0778 \pm 0.0098$ & $0.021 \pm 0.0028$ & $0.0062 \pm 0.0009$ & $0.0020 \pm 0.0002$ \\
\hline
\end{tabular}

Table 1. Phenotypical analysis of seedlings growing on medium supplement with SWCNHs at $25 \mu \mathrm{g} / \mathrm{ml}, 50 \mu \mathrm{g} / \mathrm{ml}$ and $100 \mu \mathrm{g} / \mathrm{ml}$.

Controls were grown on regular growing MS medium $(0 \mu \mathrm{g} / \mathrm{ml}) . b, p<0.05$ compared to control. \pm , SE (Standard Error). 
The most effective concentration of SWCNHs was different for different crop species. Indeed, the highest mean values of shoot length in corn and soybean was at $100 \mu \mathrm{g} / \mathrm{ml}$, while the highest mean value in rice and tomato was recorded at $50 \mu \mathrm{g} / \mathrm{ml}$. Interestingly, the root length was not affected by the addition of nanohorns to the growing medium at all used concentrations. The average length values of roots were significantly similar between exposed and non-exposed seedlings, with the exception of corn roots that have developed longer roots at $100 \mu \mathrm{g} / \mathrm{ml}$ of SWCNHs. The number of leaves calculated in corn and tomato seedlings increased significantly at concentrations of SWCNHs equal to $50 \mu \mathrm{g} / \mathrm{ml}$ and higher. SWCNHs-exposed corn, rice and soybean shoots of seedlings were more developed and have shown a significant increase of fresh weight compared to controls $(70 \%, 76 \%$ and $11 \%$, consequently). Fresh and dry roots' weights of rice exposed to SWCNHs were also significantly higher than root weights of rice control seedlings. Overall, SWCNHs have increased growth and development of specific organs (corn, tomato, soybean and rice) at different SWCNHs concentrations. Interestingly, no phenotypic changes of growth and development of barley and switchgrass were observed at all SWCNHs concentrations. Based on recorded phenotypic data, we can conclude that SWCNHs did not cause any negative effects on growth of seedlings of all six tested crop species. On the contrary, SWCNHs were able to play a role as a positive regulator in processes of crop germination and development. This observation is consistent with our previous report [9], that described the positive effect of MWCNTs on germination and development of commercially important crops (barley, corn and soybean).

We have demonstrated that carbon-based nanomaterials can, not only affect the development of whole plant, but also can cause significant changes at the cellular level. Thus, we showed that MWCNTs can stimulate growth of tobacco cell culture (callus) and activate expression of genes associated with water uptake, cell division and cell extension [47]. In order, to understand if 
SWCNHs exhibits a similar effect on cell growth, we applied SWCNHs to the same cellular system (tobacco callus) and recorded the growth of cells.

\subsection{SWCNHs Accelerates Growth of Tobacco Cell Culture}

Tobacco callus was exposed to three concentrations of SWCNHs $(25,50,100 \mu \mathrm{g} / \mathrm{ml})$. We documented the effect of stimulation of callus growth in response to the use of carbon nanohorns in two doses $(50$ and $100 \mu \mathrm{g} / \mathrm{ml})$. Figure 3A shows a representative graph of the differences in growth between the control and exposed calli to 25,50 and $100 \mu \mathrm{g} / \mathrm{ml}$ SWCNHs. The average fresh weight of callus growing on SWCNHs was enhanced by $48 \%$ and $78 \%$ compared to control at concentrations of 50 and $100 \mathrm{~g} / \mathrm{ml}$, respectively (Figure 3B).

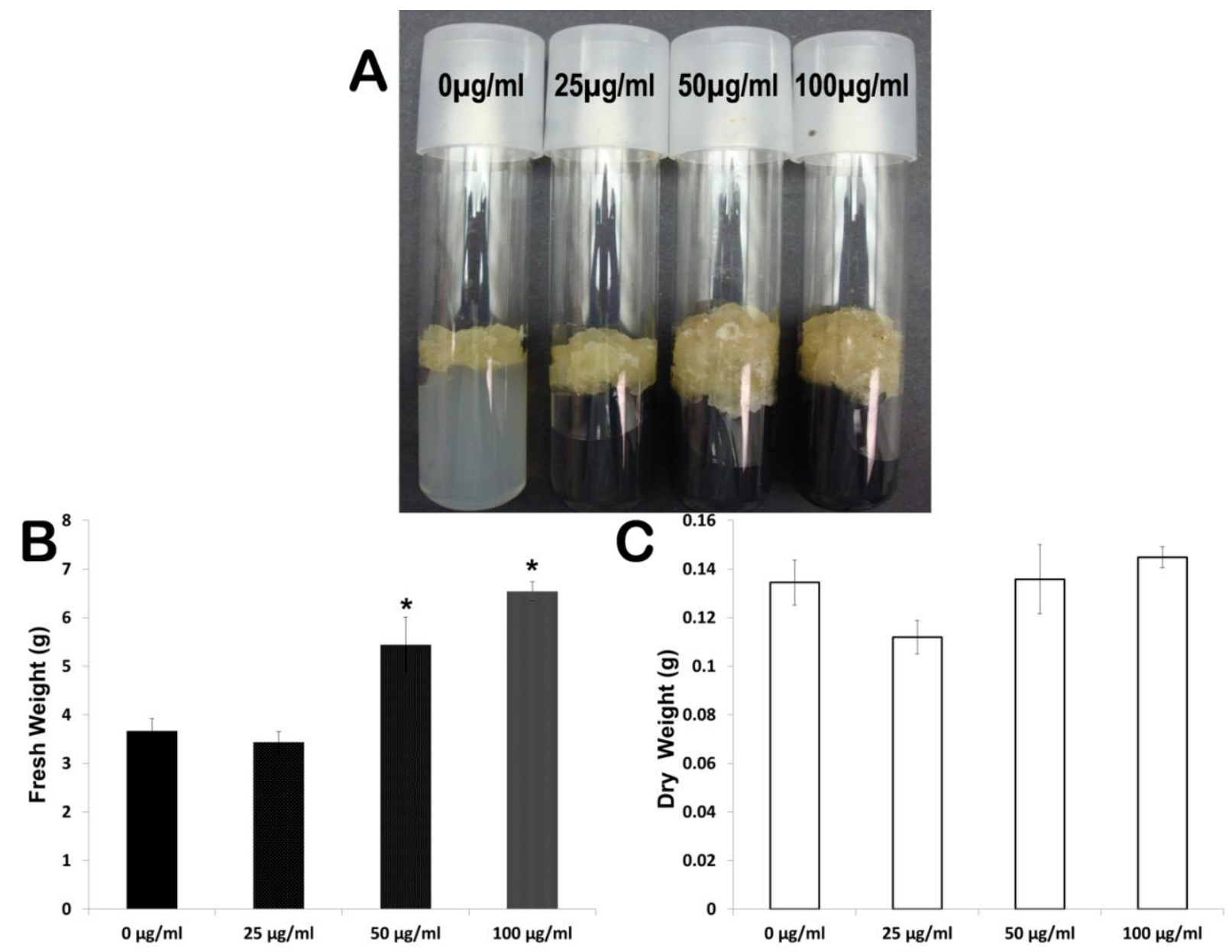


Figure 3. Effects of SWCNHs on growth of tobacco callus culture. (A) Differences of growth between callus grown on MS medium (control) and callus growing on medium supplemented with SWCNHs at concentration of $25 \mu \mathrm{g} / \mathrm{ml}, 50 \mu \mathrm{g} / \mathrm{ml}$ and $100 \mu \mathrm{g} / \mathrm{ml}$. Callus accumulation at regular medium and medium supplemented with SWCNHs at concentrations 25, 50, $100 \mu \mathrm{g} / \mathrm{ml}$. Fresh weight (B) and dry weight (C) of biomass were assessed. The initial callus amount used for all experiments was equal (300 mg). Each experimental condition was replicated 10 times. The entire experiment was repeated twice. Thus, vertical bars indicate $\pm \operatorname{SE}(n=20)$.

Callus growing on $25 \mu \mathrm{g} / \mathrm{ml}$ did not show any significant differences compared to control. The average dry weight of biomass was measured after incubation of callus at $70{ }^{\circ} \mathrm{C}$ for 24 hours. While the dry weight of callus exposed to SWCNHs was relatively higher than the control, it was not significant $(p>0.05)$. We have previously reported that MWCNTs were able to increase callus growth up to $64 \%$ at concentration of $500 \mu \mathrm{g} / \mathrm{ml}$ [47]. Here, we noticed that SWCNHs were able further to increase growth of tobacco callus up to $78 \%$ at a concentration of $100 \mu \mathrm{g} / \mathrm{ml}$. The ability of SWCNHs to increase the growth of callus similarly to MWCNTs could be explained by the physical properties shared between these carbonaceous nanomaterials. However, the reason SWCNHs have shown better results at a much lower concentration could be due to the impurities within MWCNTs that could suppress the growth of callus culture or the shape of SWCNHs that could allow better penetration of the cell membrane. The observed positive influence of SWCNHs on fresh callus biomass but not on dry weight can bring the idea that cells exposed to SWCNHs can take more water than control cells. This possibility in a good agreement with our previous findings of overexpression of water channels (aquaporins) in plant organs and cells exposed to carbon- 
based nanomaterials (carbon nanotubes). We hypothesized that overexpression of aquaporins can enhance plant water uptake and contribute in the stimulating effects of carbon nanotubes (activation of seed germination and cell growth) $[8,35,47]$. Future work can clarify if our hypothesis is correct and if it is true for other carbon-based nanomaterials.

The assessment of nanomaterials uptake by exposed plant tissues is an important part of the evaluation of nanoparticles-plant interactions. Such investigation can help clarify if documented biological effects of nanomaterial are in correlation with the uptake of such material by plants and cells.

\subsection{SWCNHs Can Be Absorbed by Plants and Plant Cells}

We examined the presence of SWCNHs in exposed plant samples using transmission electron microscopy (TEM) and microwave induced heating (MIH) technique. SWCNHs exposed and nonexposed tomato seeds and root tissues as well as tobacco callus was sliced and visualized using high resolution-TEM. We did not notice the presence of SWCNHs in unexposed (control) tissues (Figure 4A, 4B and 4C). On the other hand, TEM images of tomato seeds (24 hours incubation) in 100 $\mu \mathrm{g} / \mathrm{ml}$ SWCNHs-containing medium indicated the presence of black aggregates of SWCNHs inside the seeds (Figure 4D). Similar aggregates were found in the roots of 11 day-old tomato seedlings grown on medium supplemented with SWCNHs (Figure 4E). Tobacco callus growing on medium supplemented with SWCNHs $(100 \mu \mathrm{g} / \mathrm{ml})$ also shows the presence of "dahlia-like" shape of SWCNHs inside of cells (Figure 4F). 




Figure 4. Detection of SWCNHs in exposed tomato seeds/roots and tobacco cells (callus) using transmission electron microscopy (TEM). Arrows indicate the presence of SWCNHs. Controls were plants (A) seeds, (B) roots and (C) callus growing on regular MS medium. (D) Tomato seeds were exposed to SWCNHs $(100 \mu \mathrm{g} / \mathrm{ml})$ for 24 hours. (E) Roots were treated with SWCNHs $(100 \mu \mathrm{g} / \mathrm{ml})$ for 11 days. (F) Cells of tobacco were taken to TEM after 30 days of incubation on MS medium supplemented with SWCNHs $(100 \mu \mathrm{g} / \mathrm{ml})$.

Many groups have shown that plants can uptake different carbonaceous nanomaterials including SWCNTs and MWCNTs [9,47,48], graphene [49], and fullerenes [48,50]. We observed here that SWCNHs, like other carbon-based nanomaterials, can be absorbed by plant cells, seeds and 
roots. To further confirm the presence of SWCNHs inside plant tissue, MIH technique was applied. This method was developed recently [36], and can be used to quantify the amount of several carbon-based nanomaterials such as SWCNTs, MWCNTs and SWCNHs in plant tissue. We compared the uptake of SWCNHs between tested crop species by this method (Table 2). 


\begin{tabular}{|c|c|c|c|c|c|c|c|}
\hline Sample & $\begin{array}{l}\text { Power, } \\
\text { time }\end{array}$ & $\Delta \mathbf{T}_{\max }$ & $\begin{array}{l}\mu \mathrm{g} \text { SWCNH/ } \\
\text { mg sample }\end{array}$ & S.D & $\begin{array}{l}\mu \mathrm{g} S W C N H / \\
\text { plant root }\end{array}$ & $\begin{array}{l}\text { \% } \\
\text { plant } \\
\text { box }\end{array}$ & $\begin{array}{r}\text { SWCNH } \\
\text { uptake/ }\end{array}$ \\
\hline SWCNH & $30 \mathrm{~W}, \sim 1 \mathrm{~s}$ & 265 & & & & & \\
\hline \multirow{2}{*}{$\begin{array}{l}\text { Control barley } \\
\text { roots }\end{array}$} & $30 \mathrm{~W}, 10 \mathrm{~s}$ & 45.8 & \multirow[t]{2}{*}{0} & & & & \\
\hline & $50 \mathrm{~W}, 6 \mathrm{~s}$ & 62 & & & & & \\
\hline \multirow{2}{*}{$\begin{array}{l}\text { SWCNH treated } \\
\text { barley roots }\end{array}$} & $30 \mathrm{~W}, 10 \mathrm{~s}$ & 102.6 & \multirow[t]{2}{*}{0.074} & \multirow{2}{*}{$\begin{array}{l} \pm \\
0.025\end{array}$} & \multirow[t]{2}{*}{1.48} & \multirow{2}{*}{\multicolumn{2}{|c|}{0.025}} \\
\hline & $50 \mathrm{~W}, 6 \mathrm{~s}$ & 186.4 & & & & & \\
\hline \multirow[t]{2}{*}{ Control corn root } & $30 \mathrm{~W}, 10 \mathrm{~s}$ & 54.6 & \multirow[t]{2}{*}{0} & & & & \\
\hline & $50 \mathrm{~W}, 6 \mathrm{~s}$ & 70.6 & & & & & \\
\hline \multirow{2}{*}{$\begin{array}{l}\text { SWCNH treated } \\
\text { corn root }\end{array}$} & $30 \mathrm{~W}, 10 \mathrm{~s}$ & 144.6 & \multirow[t]{2}{*}{0.107} & \multirow{2}{*}{$\begin{array}{l} \pm \\
0.010\end{array}$} & \multirow[t]{2}{*}{24.61} & \multirow{2}{*}{\multicolumn{2}{|c|}{0.410}} \\
\hline & $50 \mathrm{~W}, 6 \mathrm{~s}$ & 210.9 & & & & & \\
\hline \multirow{2}{*}{$\begin{array}{ll}\text { Control rice } \\
\text { roots }\end{array}$} & $30 \mathrm{~W}, 10 \mathrm{~s}$ & 79.4 & \multirow[t]{2}{*}{0} & & & & \\
\hline & $50 \mathrm{~W}, 6 \mathrm{~s}$ & 103 & & & & & \\
\hline \multirow{2}{*}{$\begin{array}{l}\text { SWCNH treated } \\
\text { rice roots }\end{array}$} & $30 \mathrm{~W}, 10 \mathrm{~s}$ & 143.1 & \multirow[t]{2}{*}{0.065} & \multirow{2}{*}{$\begin{array}{l} \pm \\
0.013\end{array}$} & \multirow[t]{2}{*}{2.6} & \multirow{2}{*}{\multicolumn{2}{|c|}{0.043}} \\
\hline & $50 \mathrm{~W}, 6 \mathrm{~s}$ & 200.7 & & & & & \\
\hline \multirow{2}{*}{$\begin{array}{l}\text { Control soybean } \\
\text { roots }\end{array}$} & $30 \mathrm{~W}, 10 \mathrm{~s}$ & 54.1 & \multirow[t]{2}{*}{0} & & & & \\
\hline & $50 \mathrm{~W}, 6 \mathrm{~s}$ & 70.7 & & & & & \\
\hline \multirow{2}{*}{$\begin{array}{l}\text { SWCNH treated } \\
\text { soybean roots }\end{array}$} & $30 \mathrm{~W}, 10 \mathrm{~s}$ & 59.7 & \multirow[t]{2}{*}{0.01} & \multirow{2}{*}{$\begin{array}{l} \pm \\
0.007\end{array}$} & \multirow[t]{2}{*}{0.40} & \multirow{2}{*}{\multicolumn{2}{|c|}{0.007}} \\
\hline & $50 \mathrm{~W}, 6 \mathrm{~s}$ & 88.3 & & & & & \\
\hline \multirow{2}{*}{$\begin{array}{ll}\text { Control tomato } \\
\text { root }\end{array}$} & $30 \mathrm{~W}, 10 \mathrm{~s}$ & 34.1 & \multirow[t]{2}{*}{0} & & & & \\
\hline & $50 \mathrm{~W}, 6 \mathrm{~s}$ & 62.7 & & & & & \\
\hline \multirow{2}{*}{$\begin{array}{l}\text { SWCNH treated } \\
\text { tomato root }\end{array}$} & $30 \mathrm{~W}, 10 \mathrm{~s}$ & 310.6 & \multirow[t]{2}{*}{0.275} & \pm & 0.55 & 0.009 & \\
\hline & $50 \mathrm{~W}, 6 \mathrm{~s}$ & $\sim 479$ & & & & & \\
\hline Control tobacco & $30 \mathrm{~W}, 10 \mathrm{~s}$ & 50.8 & 0 & & & & \\
\hline & $50 \mathrm{~W}, 6 \mathrm{~s}$ & 54.5 & & & & & \\
\hline SWCNH treated & $30 \mathrm{~W}, 10 \mathrm{~s}$ & 189.4 & 0.134 & & 20.1 & 1.01 & \\
\hline & $50 \mathrm{~W}, 6 \mathrm{~s}$ & 289.2 & & & & & \\
\hline
\end{tabular}

Table 2. Quantity of SWCNH uptake by crop roots and tobacco callus determined by the microwave induced heating (MIH) detection technique. 
The control and SWCNHs-treated plant roots (corn, tomato, rice, barley, and soybean), and tobacco callus were tested at two different microwave powers (30 and $50 \mathrm{~W}$ ) over given exposure times (10 and 6 s respectively). Utilizing the calibration curve derived for SWCNHs, the unknown quantity of the SWCNHs uptake was calculated from the difference in temperature rise. The calibration curve (Figure S2) was renormalized from prior data [36] to account for differences in the nanomaterials' microwave response. This means effectively that the slope of the calibration is multiplied by a ratio based on the microwave response of the source nanomaterials. Moreover, the variation in temperature rises for various control samples was taken into consideration during the regeneration of the curves. The slope of the curves depends on the nanomaterial whereas the intercept varies with the control plant response. The amount of nanomaterial's uptake was determined from these curves and then normalized by the amount of the total sample taken. Table 2 shows the normalized value of SWCNHs uptake by the particular plant samples after treatment along with the deviation. All the tested exposed plants and callus culture showed uptake of nanomaterials. Taking into account the weight of plants, we were able to determine the approximate value of the total SWCNHs uptake by each crop. Table 2 summarizes the approximate values of SWCNHs contained per plant/tissue. The results show that the corn roots have the highest uptake of nanoparticle with a value of $0.41 \%$ per root the lowest value of nanoparticle uptake with a value of $0.007 \%$ per root was recorded in soybean roots. The SWCNHs-treated tobacco callus accumulated SWCNHs in the amount of 1.01 $\%$ from the total amount added into one cultivation vessel.

Our experiments indicated that SWCNHs can positively affect the growth of plants. We have tried to correlate data of size of plants, length of the root system, fresh/dry weight of seedlings with amount of absorbed nanohorns (data not shown). No significant correlations were found. We can suggest that observed differences in growth response of tested crops can be associated not only with 
the amount of absorbed nanohorns but with other parameters as well. Such traits as differences in physiology, channel work, rate of photosynthesis, sensitivity to specific stress factors can play a critical role in SWCNHs related growth response of different crop species.

It is known that standard methods for detection of carbonaceous nanomaterials in plants (PA/PT spectroscopy, Raman spectroscopy, TEM) can indicate clearly the presence of nanomaterial inside plant cell or plant organ but are not sufficient enough for quantitative estimation of absorbed nanomaterial. MIH technique can provide a good opportunity to quantify the total amount of carbon nanomaterials inside exposed plant and compare the uptake between plant species as well as between different plant tissues. This method indicated that roots of tested crops can absorb relatively small amount of nanohorns from total supplied material. However, even small amount of nano-sized material can modify the response of exposed plants at transcriptome and proteome levels.

\subsection{SWCNHs Affect Total Transcriptome of Exposed Tomato Seeds and Seedlings}

Understanding the impact of nanosized materials at the genetic level is an important step in the evaluation of the molecular base for observed biological effects associated with the application of materials. Microarray technology is well-known and effective approach for comparative transcriptome profiling in plants [51]. Using an Affymetrix ${ }^{\circledR}$ Array Gene Chip platform we investigated the effect of SWCNHs on total gene expression in unexposed (control) and exposed tomato seeds/seedlings. With a $p<0.01$, we performed an unpaired t-test analysis and showed that 78 genes in seeds (Figure S2) and 336 genes in seedlings (Figure S3) were significantly affected by application of SWCNHs. Among these genes, only 15 genes in seeds (Figure 5) and 78 genes in seedlings (Figure 6) were annotated as genes with known functions according to the NCBI website. 


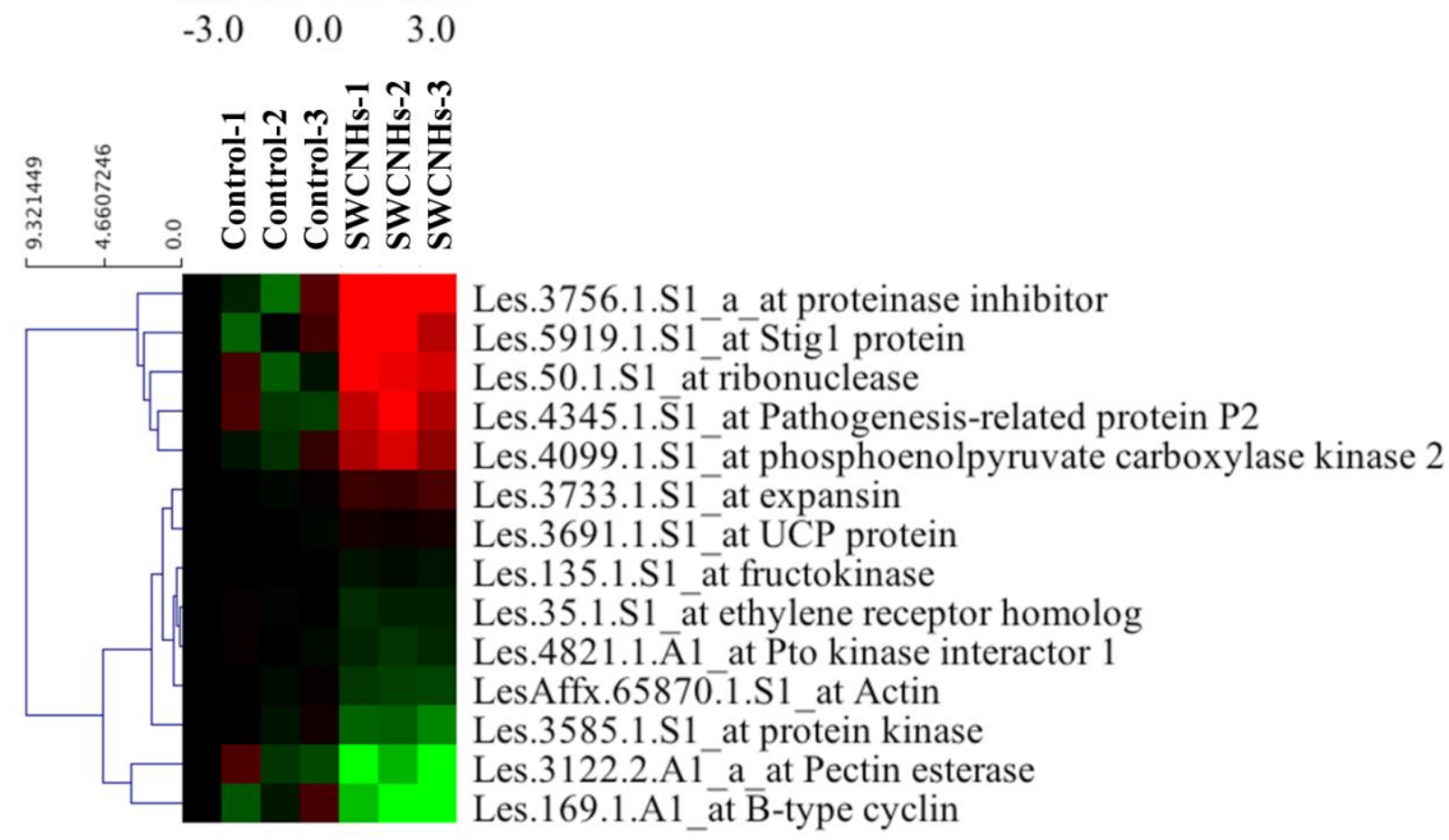

Figure 5. Microarray data of significant genes altered by SWCNHs treatment in exposed tomato seeds. Seeds were incubated on medium containing SWCNHs or without SWCNHs (Control) for 24 hours and then harvested for analysis. Significantly altered genes were determined after statistical analysis with a $p$-value $<0.01$. Only genes with known function are presented here. 


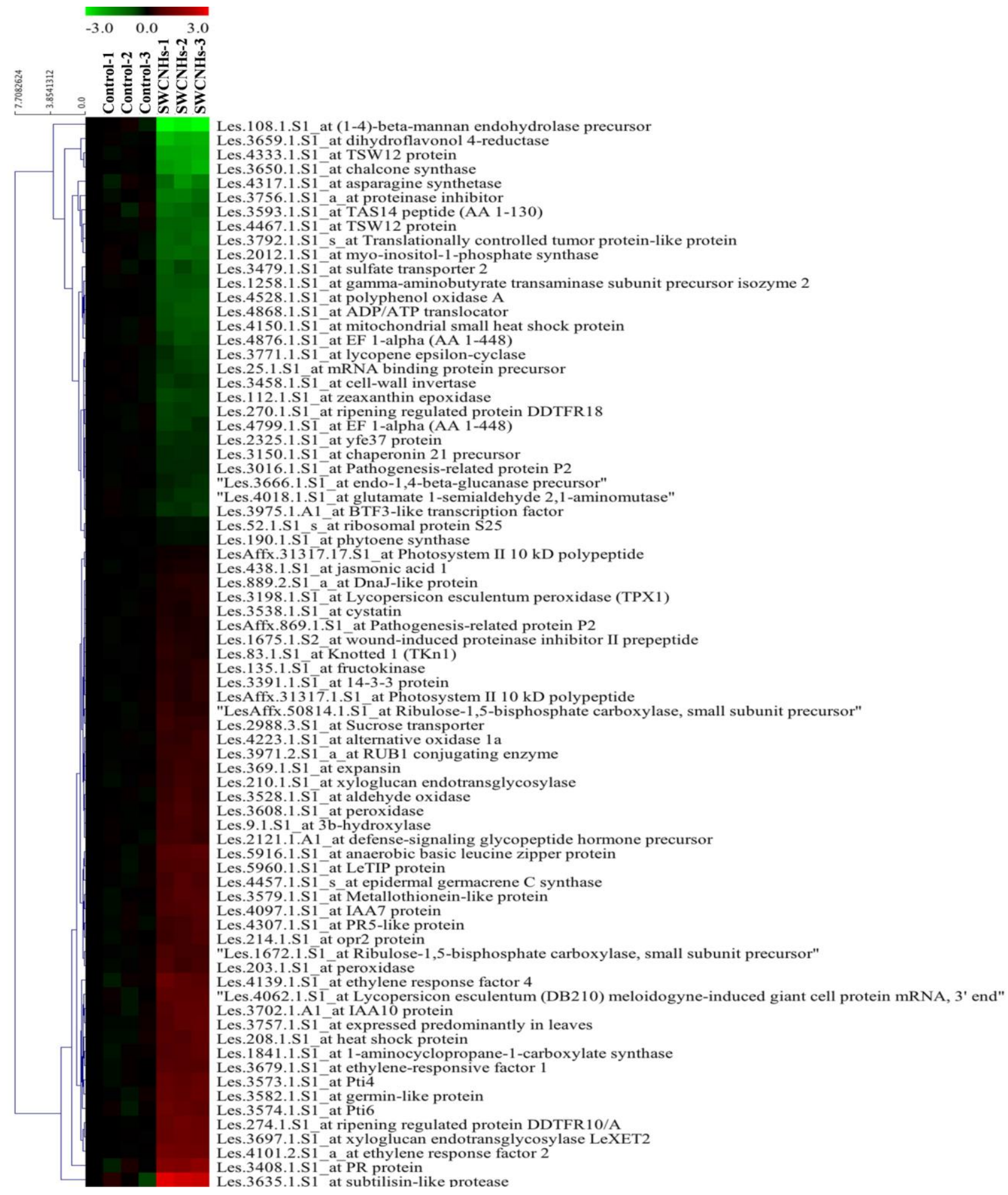

Figure 6. Microarray data of significant genes altered by SWCNHs treatment in tomato seedling. Seedling (11 day-old) were growing on medium supplemented with SWCNHs or without SWCNHs 
(Control) for 24 hours and then harvested for analysis. Significantly altered genes were determined after statistical analysis with a $p$-value $<0.01$. Only genes with known function are presented here.

The heat map figure of seeds exposed to SWCNHs shows that a total of 7 genes were up-regulated while 8 were down regulated. In seedlings, we found that 32 genes were up-regulated while 46 were down- regulated. The functional categorization of genes that were up- and down- regulated by exposure to SWCNHs was performed using the Tomato Functional Genomics Database. Supplemental figure S5 summarizes the specific biological processes altered by the exposure of seeds and seedling to SWCNHs. The total profiles of genes altered by application of carbon nanohorns in both tomato plant tissues are relatively similar. We can distinguish three major processes including cellular response, stress response and metabolic process. In seeds, the majority of genes regulated by SWCNHs were involved in the cellular response ( 25 genes), response to stress (18 genes) and metabolic process (15 genes). In seedlings, a larger number of genes were involved in the cellular response (100 genes) response to stress ( 89 genes) and metabolic process (50 genes). In both tissues, many genes were activated in response to stress (13 genes in seeds and 56 genes in seedlings). For example, jasmonic acid1 (Les.438.1.S1_at) an important regulator of plant response to stress was up-regulated. In addition, many pathogenesis related genes were up regulated in the response to SWCNHs treatment including cystatine (Les.3538.1.S1_at), the tomato transcription factors Pti4 (Les.3573.1.S1_at) and Pti6 (Les.3574.1.S1_at), peroxidase (Les.203.1.S1_at) and ethylene-responsive factor1 (Les.3679.1.S1_at) [52-54] . Furthermore, the up-regulation of expansin (Les.369.1.S1_at) in seedlings as well as in seeds was intriguing. Indeed, expansin belong to the family of protein found in the cell wall, with important roles in plant cell growth, fruit softening, abscission, emergence of root hairs, pollen tube invasion, meristem 
function, and other developmental processes [55]. In general, microarray analysis revealed that similarly with carbon nanotubes $[8,47]$. SWCNHs can affect stress signaling in plants as well as expression of genes associated with cell growth. Such changes at the molecular level can make a major contribution in observed phenomenon of enhancement of productivity of plants exposed to tested nanomaterials. To validate the microarray data, we generated sequence specific primers and performed quantitative real-time reverse transcription polymerase chain reaction (RT-qPCR) using two independent biological replicates for three identified up-regulated genes in tomato tissues: ribonuclease (Les.50.1.S1_at), subtilise-like protease (Les.3635.1S1_at) and 1-aminocyclopropane1-carboxylate synthase (Les.1841.1.S1_at). The real-time PCR data confirmed the above microarray data (Figure S6). Indeed, these three genes were confirmed to be up-regulated in the SWCNHs treated tomato seeds and seedlings as observed in microarray data.

\section{Conclusion}

Carbon-based nanomaterials have found a range of application in different biological systems [6]. While investigations on the biological effects of graphene and carbon nanotubes have attracted many scientists, other carbon-based nanomaterials did not get as much attention [6]. Carbon nanohorns are among the relatively new nanomaterials that require further investigation in different biological systems due to their unique properties. To our best knowledge, this is the first study on the interactions of plant tissues (in vivo and in vitro) with SWCNHs. Based on our experimental data, we can conclude that SWCNHs, in relatively low doses, can be easily absorbed by roots and cells without any toxic effects for a number of crop species as well as for plant cell culture (tobacco callus). On the contrary, SWCNHs can significantly activate seed germination and cell growth. Comparative analysis of tomato microarray data generated from experiments involved SWCNHs 
and data of previous experiments involved MWCNTs [8], revealed that both types of carbonaceous material can affect stress signaling in planta. In general, our experiments proved that nanohorns can be an attractive nanosized material for plant-related applications. SWCNHs don't display negative effects in plant system but exhibit some advantages in shape and surface chemistry in comparison with other carbonaceous materials. Further experiments related to testing of SWCNHs as carriers of chemicals or nucleic acids to plant organs are needed.

\section{Acknowledgements}

Synthesis/characterization of nanohorns and TEM experiments were conducted at the Center for Nanophase Materials Sciences, which is sponsored at Oak Ridge National Laboratory by the Division of Scientific User Facilities, Office of Basic Energy Sciences, and U.S. Department of Energy. We are grateful to Mrs. Valerie K. Lapham (Center for Electron Microscopy, North Carolina State University) for help with preparation of TEM grids. We are grateful to Syngenta Crop Protection AG (Basel, Switzerland) for financial support to Mohamed H. Lahiani. Dr. Green acknowledges funding from NSF award CBET-1133250.

\section{Appendix A. Supplementary data}

Supplementary data associated with this article can be found in the online version, at http://www.sciencedirect.com. It includes additional data related to the phenotype of different plants, the calibration curve for the detection of SWCNHs in plant samples by MIH technique, total transcript profile of known and unknown genes significantly affected by exposure to SWCNHs in 
seeds and seedlings and a summary of total biological processes affected by SWCNHs treatment in seeds and seedlings.

\section{REFERENCES}

[1] Mink JE, Hussain MM. Sustainable design of high-performance microsized microbial fuel cell with carbon nanotube anode and air cathode. ACS Nano 2013;7:6921-7.

[2] Kumar S, Bhanjana G, Jangra K, Dilbaghi N, Umar A. Utilization of carbon nanotubes for the removal of rhodamine B dye from aqueous solutions. J Nanosci Nanotechnol 2014;14:4331-6.

[3] Landers J, Turner JT, Heden G, Carlson AL, Bennett NK, Moghe PV et al. Carbon Nanotube Composites as Multifunctional Substrates for In Situ Actuation of Differentiation of Human Neural Stem Cells. Adv Healthc Mater 2014.

[4] Whitney JR, Rodgers A, Harvie E, Carswell WF, Torti S, Puretzky AA et al. Spatial and temporal measurements of temperature and cell viability in response to nanoparticle-mediated photothermal therapy. Nanomedicine (Lond) 2012;7:1729-42.

[5] Whitney JR, Sarkar S, Zhang J, Do T, Young T, Manson MK et al. Single walled carbon nanohorns as photothermal cancer agents. Lasers Surg Med 2011;43:43-51.

[6] Zhang BT, Zheng X, Li HF, Lin JM. Application of carbon-based nanomaterials in sample preparation: a review. Anal Chim Acta 2013;784:1-17.

[7] Canas JE, Long M, Nations S, Vadan R, Dai L, Luo M et al. Effects of functionalized and nonfunctionalized single-walled carbon nanotubes on root elongation of select crop species. Environ Toxicol Chem 2008;27:1922-31.

[8] Khodakovskaya MV, de Silva K, Nedosekin DA, Dervishi E, Biris AS, Shashkov EV et al. Complex genetic, photothermal, and photoacoustic analysis of nanoparticle-plant interactions. Proc Natl Acad Sci U S A 2011;108:1028-33.

[9] Lahiani MH, Dervishi E, Chen J, Nima Z, Gaume A, Biris AS et al. Impact of carbon nanotube exposure to seeds of valuable crops. ACS Appl Mater Interfaces 2013;5:7965-73.

[10] Gonzalez-Melendi P, Fernandez-Pacheco R, Coronado MJ, Corredor E, Testillano PS, Risueno MC et al. Nanoparticles as smart treatment delivery systems in plants: assessment of different techniques of microscopy for their visualisation in plant tissues. Ann Bot-London 2008;101:187-95.

[11] Awasthi K, Singh DP, Singh SK, Dash D, Srivastava ON. Attachment of biomolecules (protein and DNA) to amino-functionalized carbon nanotubes. New Carbon Materials 2009;24:301-6.

[12] Galbraith DW. Nanobiotechnology: silica breaks through in plants. Nat Nanotechnol 2007;2:272-3. 
[13] Harrison BS, Atala A. Carbon nanotube applications for tissue engineering. Biomaterials 2007;28:34453.

[14] Miyawaki J, Yudasaka M, Iijima S. Solvent Effects on Hole-Edge Structure for Single-Wall Carbon Nanotubes and Single-Wall Carbon Nanohorns. J Phys Chem B 2004;108:10732-5.

[15] Miyawaki J, Yudasaka M, Azami T, Kubo Y, Iijima S. Toxicity of Single-Walled Carbon Nanohorns. ACS Nano 2008;2:213-26.

[16] Zhu S, Xu G. Single-walled carbon nanohorns and their applications. Nanoscale 2010;2:2538-49.

[17] Xu J, Tomimoto H, Nakayama T. What is inside carbon nanohorn aggregates? Carbon 2011;49:2074-8.

[18] Azami T, Kasuya D, Yuge R, Yudasaka M, Iijima S, Yoshitake T et al. Large-Scale Production of Single-Wall Carbon Nanohorns with High Purity. J Phys Chem C 2008;112:1330-4.

[19] Ambrosi A, Pumera M. The CVD graphene transfer procedure introduces metallic impurities which alter the graphene electrochemical properties. Nanoscale 2014;6:472-6.

[20] Ge C, Lao F, Li W, Li Y, Chen C, Qiu Y et al. Quantitative Analysis of Metal Impurities in Carbon Nanotubes: Efficacy of Different Pretreatment Protocols for ICPMS Spectroscopy. Anal Chem 2008;80:9426-34.

[21] Goyal RN, Kaur D, Singh SP, Pandey AK. Effect of graphite and metallic impurities of C60 fullerene on determination of salbutamol in biological fluids. Talanta 2008;75:63-9.

[22] Turner S, Lebedev OI, Shenderova O, Vlasov II, Verbeeck J, Van Tendeloo G. Determination of Size, Morphology, and Nitrogen Impurity Location in Treated Detonation Nanodiamond by Transmission Electron Microscopy $<$ br />. Adv Funct Mater 2009;19:2116-2124.

[23] Martin-Gullon I, Vera J, Conesa JA, González JL, Merino C. Differences between carbon nanofibers produced using Fe and Ni catalysts in a floating catalyst reactor. Carbon 2006;44:1572-80.

[24] Iijima S, Yudasaka M, Yamada R, Bandow S, Suenaga K, Kokai F et al. Nano-aggregates of singlewalled graphitic carbon nano-horns. Chemical Physics Letters 1999;309:165-70.

[25] Kasuya D, Yudasaka M, Takahashi K, Kokai F, Iijima S. Selective Production of Single-Wall Carbon Nanohorn Aggregates and Their Formation Mechanism. J Phys Chem B 2002;106:4947-51.

[26] Murata K, Kaneko K, Kanoh H, Kasuya D, Takahashi K, Kokai F et al. Adsorption Mechanism of Supercritical Hydrogen in Internal and Interstitial Nanospaces of Single-Wall Carbon Nanohorn Assembly. J Phys Chem B 2002;106:11132-8.

[27] Bekyarova E, Kaneko K, Yudasaka M, Kasuya D, Iijima S, Huidobro A et al. Controlled Opening of Single-Wall Carbon Nanohorns by Heat Treatment in Carbon Dioxide. J Phys Chem B 2003;107:4479-84.

[28] Sano N, Taniguchi K, Tamon H. Hydrogen Storage in Porous Single-Walled Carbon Nanohorns Dispersed with Pdâ€"Ni Alloy Nanoparticles. J Phys Chem C 2014;118:3402-8. 
[29] Zambano AJ, Talapatra S, Lafdi K, Aziz MT, McMillin W, Shaughnessy G et al. Adsorbate binding energy and adsorption capacity of xenon on carbon nanohorns. Nanotechnology 2002;13:201.

[30] Yamazaki K, Shinke K, Ogino T. Selective adsorption of bilirubin against albumin to oxidized singlewall carbon nanohorns. Colloids Surf B Biointerfaces 2013;112:103-7.

[31] Dewitt MR, Pekkanen AM, Robertson J, Rylander CG, Nichole Rylander M. Influence of hyperthermia on efficacy and uptake of carbon nanohorn-Cisplatin $\backslash$ conjugates. J Biomech Eng

2014;136:10.1115/1.4026318.

[32] Zhang P, Ma Y, Zhang Z, He X, Zhang J, Guo Z et al. Biotransformation of Ceria Nanoparticles in Cucumber Plants. ACS Nano 2012;6:9943-50.

[33] Ajima K, Yudasaka M, Murakami T, MaignÃ® A, Shiba K, lijima S. Carbon Nanohorns as Anticancer Drug Carriers. Mol Pharmaceutics 2005;2:475-80.

[34] Zhang M, Yamaguchi T, Iijima S, Yudasaka M. Size-dependent biodistribution of carbon nanohorns in vivo. Nanomedicine 2013;9:657-64.

[35] Villagarcia H, Dervishi E, de Silva K, Biris AS, Khodakovskaya MV. Surface Chemistry of Carbon Nanotubes Impacts the Growth and Expression of Water Channel Protein in Tomato Plants. Small 2012;8:2328-34.

[36] Irin F, Shrestha B, Cañas JE, Saed MA, Green MJ. Detection of carbon nanotubes in biological samples through microwave-induced heating. Carbon 2012;50:4441-9.

[37] Puretzky AA, Styers-Barnett D, Rouleau CM, Hu H, Zhao B, Ivanov IN et al. Cumulative and continuous laser vaporization synthesis of single wall carbon nanotubes and nanohorns. Applied Physics A 2008;93:849-55.

[38] Cheng M, Lee D, Zhao B, Hu H, Styers-Barnett DJ, Puretzky AA et al. Formation studies and controlled production of carbon nanohorns using continuous in situ characterization techniques. Nanotechnology 2007; 18:185604.

[39] Paz M, Martinez J, Kalvig A, Fonger T, Wang K. Improved cotyledonary node method using an alternative explant derived from mature seed for efficient Agrobacterium-mediated soybean transformation. Plant Cell Rep 2006;25:206-13.

[40] Chen X, Equi R, Baxter H, Berk K, Han J, Agarwal S et al. A high-throughput transient gene expression system for switchgrass (Panicum virgatum L.) seedlings. Biotechnology for Biofuels 2010;3:9.

[41] Oyebanji OB, Nweke O, Odebunmi O, Galadima NB, Idris MS, Nnodi UN et al. Simple, effective and economical explant surface sterili-zeation protocol for cowpea, rice and sorghum Seeds. Afri J Biotechnol 2009;8:5395-5399.

[42] Brandizzi F. Ruzin SE. 1999. Plant microtechnique and microscopy. 322 pp. Oxford, New York: Oxford University Press. Annals of Botany 2000;86:708-. 
[43] Geohegan D, Puretzky A, Rouleau C, Jackson J, Eres G, Liu Z et al. Laser Interactions in Nanomaterials Synthesis. In: Miotello A, Ossi PM, editors. : Springer Berlin Heidelberg; 2010, p. 1-17.

[44] Geohegan D, Puretzky A, Yoon M, Eres G, Rouleau C, Xiao K et al. Laser Interactions for the Synthesis and In Situ Diagnostics of Nanomaterials. In: Castillejo M, Ossi PM, Zhigilei L, editors. : Springer International Publishing; 2014, p. 143-173.

[45] Liu Y, Brown CM, Neumann DA, Geohegan DB, Puretzky AA, Rouleau CM et al. Metal-assisted hydrogen storage on Pt-decorated single-walled carbon nanohorns. Carbon 2012;50:4953-64.

[46] Oakes L, Westover A, Mahjouri-Samani M, Chatterjee S, Puretzky AA, Rouleau C et al. Uniform, Homogenous Coatings of Carbon Nanohorns on Arbitrary Substrates from Common Solvents. ACS Appl Mater Interfaces 2013;5:13153-60.

[47] Khodakovskaya MV, de Silva K, Biris AS, Dervishi E, Villagarcia H. Carbon nanotubes induce growth enhancement of tobacco cells. ACS Nano 2012;6:2128-35.

[48] Torre DL, Hawthorne JF, Deng YF, Xing BF, Cai W FAU - Newman, Lee,A., FAU NL et al. Fullereneenhanced accumulation of p,p'-DDE in agricultural crop species. Environmental science \& technology JID 02131550122.

[49] Begum P, Ikhtiari R, Fugetsu B. Graphene phytotoxicity in the seedling stage of cabbage, tomato, red spinach, and lettuce. Carbon 2011;49:3907-19.

[50] Avanasi R, Jackson WA, Sherwin B, Mudge JF, Anderson TA. C60 Fullerene Soil Sorption, Biodegradation, and Plant Uptake. Environ Sci Technol 2014;48:2792-7.

[51] Wu S, Ramonell K, Gollub J, Somerville S. Plant gene expression profiling with DNA microarrays. Plant Physiology and Biochemistry 2001;39:917-26.

[52] Gu Y, Wildermuth MC, Chakravarthy S, Loh Y, Yang C, He X et al. Tomato Transcription Factors Pti4, Pti5, and Pti6 Activate Defense Responses When Expressed in Arabidopsis. The Plant Cell Online 2002;14:817-31.

[53] Lorenzo O, Piqueras R, Sanchez-Serrano JJ, Solano R. ETHYLENE RESPONSE FACTOR1 integrates signals from ethylene and jasmonate pathwayslin plant defense. Plant Cell 2003;15:165-78.

[54] Sarowar S, Kim Y, Kim E, Kim K, Choi J, Hyung N et al. Constitutive expression of two pathogenesisrelated genes in tomato plants enhanced resistance to oomycete pathogen Phytophthora capsici. Plant Cell, Tissue and Organ Culture 2006;86:7-14.

[55] Li Y, Jones L, McQueen-Mason S. Expansins and cell growth. Curr Opin Plant Biol 2003;6:603-10. 